\title{
The Cellular Origins of Corticotropin and Melanotropin as Revealed by Immunochemical Staining '
}

\author{
BURTON L. BAKER AND SISTER THERESE DRUMMOND ${ }^{2}$ \\ Department of Anatomy, The University of Michigan Medical School, \\ Ann Arbor, Michigan 48104
}

\begin{abstract}
The cellular origins of corticotropin and melanotropin were studied by observing the response of the rat hypophysis to adrenalectomy and cortisol administration when stained immunochemically with peroxidase-labeled antibody following application of antiserums to $\beta^{1-24}$-corticotropin, $\beta_{\mathbf{F}}{ }^{17-39}$-corticotropin, human $\beta$-melanotropin, and $a$-melanotropin. The presence of corticotropin in the pars intermedia is indicated since this lobe, in addition to corticotropic cells of the pars distalis, stained with antiserum to $\beta_{\mathrm{P}}{ }^{17-39}$-corticotropin. However, the concentration of corticotropin is less in the pars intermedia than in corticotropic cells since at higher dilutions of antiserum the latter cells stained intensely while the pars intermedia was unstained. Also, corticotropic cells exhibited striking hypertrophy after adrenalectomy and regression after cortisol administration, while morphological and tinctorial properties of the pars intermedia were minimally altered. These observations suggest that the pars distalis is primarily responsible for supplying the corticotropin required to meet the changing requirements of the body.

With antiserum to human $\beta$-melanotropin, the pars intermedia stained intensely. Since the antiserum was ineffective after absorption the staining reaction appears to be specific for $\beta$-melanotropin. Except for a rare cell, the pars distalis did not stain. Thus $\beta$-melanotropin is restricted primarily to the pars intermedia.
\end{abstract}

Several observations implicate the pars intermedia of the rat hypophysis in the secretion of corticotropin. First, both parenchymal cells of the pars intermedia (Purves and Bassett, '63) and many corticotropic cells (Hess et al., '68; Baker et al., '70) of the pars distalis stain with aldehydefuchsin and the periodic acid-Schiff procedure, indicating a similarity in their chemical composition. Second, with electron microscopy two types of cells have been described in the pars intermedia (Kurosumi et al., '61; Porte et al., '71) and Kobayashi ('65) found enlargement and accumulation of vesicles in "light" cells of the pars intermedia after adrenalectomy. Third, as revealed by labeling of DNA with ${ }^{3} \mathrm{H}$-thymidine followed by autoradiography, Gosbee et al. ('70) reported an increase in the labeling index of the pars intermedia after adrenalectomy and a decrease after cortisol administration, these situations being accompanied by an elevation and a decline, respectively, in the pituitary cortico- tropin content. Also in microscopic sections prepared with histological staining procedures, they observed an increased number of "dark" cells in the pars intermedia after adrenalectomy and no cytological change in the pars distalis. Fourth, all investigators who have utilized immunofluorescence or immunohistochemical procedures for demonstrating the cellular origin of corticotropin have observed that the pars intermedia stains in addition to corticotropic cells of the pars distalis. This result has been obtained with antiserums to $a_{\mathrm{P}}$-corticotropin ${ }^{3}$ (Nakane, '70; Baker et al., '70), synthetic $\beta^{1-24}$-corticotropin (Hess et al., '68), and $\beta_{\mathbf{P}^{17-39}}$-corticotropin (Phifer and Spicer, '70).

Prior attempts to correlate changes in corticotropin content with cytology of the hypophysis have been unsuccessful when histological staining techniques were used

\footnotetext{
1 Supported in part by NIH grant HD-03159-04.

1 Supported in part by NIH grant HD-03159-04. 2 Present address: Instituto de Nutricão, Universi-
dade Federal de Pernambuco, Recife, Pernambuco, Brazil.
} 
TABLE 1

The effect of absorption with hormones on the utility of antiserums to corticotropin and melanotropin for immunochemical staining

\begin{tabular}{|c|c|c|c|c|}
\hline \multirow{2}{*}{$\begin{array}{l}\text { Hormone } \\
\text { absorbant }\end{array}$} & \multicolumn{4}{|c|}{ Antiserum } \\
\hline & $\begin{array}{c}\beta^{1-24} \\
\text { corticotropin } 1\end{array}$ & $\frac{\beta_{\mathrm{P}} 17-39_{-}}{\text {corticotropin I }}$ & $\begin{array}{c}a- \\
\text { melanotropin } 2\end{array}$ & $\begin{array}{c}\beta- \\
\text { melanotropin } 2\end{array}$ \\
\hline$\beta^{1-24}$ & & & & \\
\hline corticotropin & 0 & t. & + & + \\
\hline $\begin{array}{c}\beta_{p^{17-39}} \\
\text { corticotropin }\end{array}$ & 0 & 0 & + & $\frac{1}{1}$ \\
\hline melanotropin & + & + & + & 0 \\
\hline
\end{tabular}

because the corticotropic cell could not be identified. This difficulty is alleviated with immunochemical staining and experimental proof that the procedure is specific for demonstration of corticotropic cells when used with anti- $\gamma_{\mathrm{p}}$-corticotropin has been presented (Baker, et al., '70).

Reported here is a comparative study of the responses of the pars intermedia and pars distalis to adrenalectomy and cortisol administration carried out to secure additional information about the origins of corticotropin and melanotropin (MSH). For this purpose, antiserums ${ }^{3}$ to $\beta^{1-21}$ corticotropin, $\beta 1^{17-39}$-corticotropin, human $\beta$ melanotropin, and $\alpha$-melanotropin were used with the immunochemical procedure.

\section{MATERIALS AND METHODS}

Young adult Sprague-Dawley rats were killed by decapitation and their hypophyses fixed in Bouin's fluid. After being embedded in paraffin the glands were cut at $3 \mu$. Immunochemical staining of sections from various regions of the gland was carried out with the peroxidase-labeled antibody procedure of Nakane and Pierce ('67), 3,3'diaminobenzidine being used as substrate for the peroxidase reaction. For preparation of antiserums, rabbits weighing $2-4$ $\mathrm{kg}$ received injections of synthetic $\beta^{1-24}$ corticotropin, ${ }^{4} \beta_{\mathrm{F}^{17-39}}$-corticotropin, human $\beta$-melanotropin or $\alpha$-melanotropin suspended in complete Freund's adjuvant, the rabbits being injected and bled as described by Midgley et al. ('71).

For study of the influence of adrenalectomy, rats were killed at weekly intervals after the operation. At one week, the adrenalectomized rats included 12 males and 10 females with 10 males and 13 females serving as controls; at two weeks, 4 male and 4 female adrenalectomized rats with 4 male and 3 female controls; and at 3 weeks, 5 adrenalectomized and 5 control male rats. The controls for the oneweek group were sham-operated. All adrenalectomized animals received $1 \% \mathrm{NaCl}$ solution as drinking fluid. For study of the effects of cortisol, five male rats received daily for 19 days $5 \mathrm{mg}(0.5 \mathrm{ml})$ of cortisol acetate suspended in Upjohn vehicle 98 (carboxymethylcellulose, polysorbate, and propylparaben) diluted $1: 2$ with $0.9 \%$ $\mathrm{NaCl}$. The control rats received an equivalent volume of vehicle.

Since immunological cross-reaction may be expected between corticotropin and melanotropin because an identical sevenamino acid sequence occurs in the two hormones, immunological controls were required to validate the specificity of the immunochemical procedure. Hence, each hormone antiserum was absorbed with each of the four hormones before use (table 1 )

\footnotetext{
3 The nomenclature recommended by $\mathrm{Li}$ (' 59 ) for corticotropin will be followed in part with a indicating the natural intact hormone; $\beta$, other molecules having corticotropic activity; superscript numbers, the amino acid residues included; and subscript letters, the species of origin. Thus, $\beta_{1}, 17-39$-corticotropin connotes the synthetic fragment of the porcine hormone. No subscript is used for $\beta^{1-24}$-corticotropin since this sequence is common to sheep, beef, pig and man (Li '59; Riniker et al., '72). The term "corticotropic cell" will designate corticotropin-containing cells of the pars distalis only.

4 We are deeply grateful to Organon, Inc., W. Orange, N.J., for supplying $\beta^{1-24}$-corticotropin (Cosyntropin (1) and to Professor H. J. Bein and Doctor W. Rittel of Ciba-Geigy Ltd. Basle, Switzerland for $\beta_{\mathrm{P}}{ }^{17-39-c o r t i c o t r o p i n,} \beta$-melanotropin, and $a$-melanotropin.
} 
to see if staining could be prevented. In so doing, the antiserum was used at the maximal dilution that, without absorption, would permit strong staining. The absorbing hormone was dissolved in physiological buffered saline and employed at several concentrations. Absorption studies with amelanotropin were unsatisfactory because of its low solubility.

\section{OBSERVATIONS}

\section{Immunological controls}

The following observations suggest that the antiserums to the corticotropins and $\beta$ melanotropin may be used for immunochemical, specific intracellular localization of these hormones in the rat hypophysis. The utility of anti- $\beta^{1-24}$-corticotropin was lost after absorption with $\beta^{1-24}$ and $\beta^{17-39}$ corticotropins (table 1 ). This result was unexpected with $\beta_{\mathrm{P}^{17-39}}$-corticotropin but could have resulted from the identity of the 17-24 sequence of amino acids in the two molecules. Although antibodies to $\beta_{\mathrm{P}}{ }^{17-39}$-corticotropin were removed from the serum by absorption with the same hormone, they apparently did not couple with molecules of $\beta^{1-24}$-corticotropin. Antiserum to each of the corticotropins was unaffected by absorption with $\beta$-melanotropin. Anti- $\beta$ melanotropin was neutralized by absorption with $\beta$-melanotropin, but its effectiveness was not altered by absorption with either $\beta^{1-24}$ - or $\beta_{\mathrm{P}}{ }^{17-39}$-corticotropin. Thus, cross-reaction between the corticotropins and $\beta$-melanotropin was not an interfering factor.

\section{The normal hypophysis}

Pars distalis. As revealed by immunochemical staining with anti- $\alpha_{\mathrm{p}}$-corticotropin (Nakane, '70; Baker, '70; Baker et al., '70), anti- $\beta_{\mathrm{P}}{ }^{17-39}$-corticotropin (fig. 1) or anti$\beta^{1-24}$-corticotropin (fig. 4), corticotropic cells of the rat pars distalis are small, stellate (fig. 7), constitute a low percentage of the cell population, and are distributed diffusely through most of the lobe. Comparison of adjacent sections, each of which was stained with one of these antiserums, revealed that a single cell type was demonstrated.

In hypophyses from control rats of both sex€s stained with anti- $\beta$-melanotropin (fig. 5), a rare intensely stained polygonal cell appeared in the pars distalis, not more than eight ever having been observed in a single section of the gland. The staining obtained with anti- $\alpha$-melanotropin varied according to the antiserum used. With one antiserum numerous ovoid cells were delineated (fig. 6 ) most of them being located near the cephalic and caudal borders of the lateral wings of the pars distalis. These cells appeared to be included among the gonadotropic cells. Another antiserum to a-melanotropin brought out these cells in addition to the rare ones stained with anti$\beta$-melanotropin.

Pars intermedia. Composing the rat pars intermedia is the pars intermedia proper consisting of several layers of polygonal cells and a narrow marginal zone made up of somewhat flattened cells that faces the residual cleft (Kurosumi et al., '62). With all antiserums used the marginal zone and colloid in the residual cleft failed to stain.

Application of the immunochemical procedure with anti- $\beta^{1-24}$-corticotropin to hypophyses of control rats stained almost all parenchymal cells in the pars intermedia proper (figs. 4, 12, 16). However, the apices of cells facing the marginal zone on one side, or the pars nervosa on the other (figs. 12,16 ), were more intensely colored. Especially in the most lateral (Kobayashi, '65) external region of the pars intermedia a few nonstaining cells were evident. With anti- $\beta_{\mathrm{P}}{ }^{17-39}$-corticotropin (figs, $1,9,15$ ) the distribution of stain in the pars intermedia proper was similar to that described for anti- $\beta^{1-24}$-corticotropin except that in some cases a more clear distinction could of ten be made between cells that stained well and those that did not.

If either anti- $\beta^{1-24}$ - or anti- $\beta_{\mathrm{P}}{ }^{17-39}$-corticotropin was used at the highest dilution that would permit nearly maximal staining of corticotropic cells in the pars distalis, no staining of the pars intermedia occurred. This observation indicates clearly that if corticotropin occurs in the pars intermedia, its concentration there is far less than in corticotropic cells of the pars distalis.

With anti- $\beta$-melanotropin, cells of the pars intermedia proper generally stained quite uniformly (figs. 5, 13); however, in the lateral region some cells contained no brown deposit at all. As with antiserums 
to corticotropin, cells facing the marginal zone or pars nervosa colored most intensely. Thus, the pars intermedia responded similarly with anti- $\beta^{1-24}$-corticotropin and anti- $\beta$ melanotropin. In all cells stained with anti- $\beta^{1-24}$-corticotropin (fig. 16), anti- $\beta_{\mathbf{P}^{17-39}}$ corticotropin (fig. 15) or anti- $\beta$-melanotropin, some darkly stained cytoplasmic structures were punctate and may correspond to the granules observed by others with electron microscopy.

With one exception all antiserums to $\alpha$ melanotropin did not permit immunochemical staining of the pars intermedia (fig. 6).

In the pars nervosa some structures stained with anti- $\beta$-melanotropin when used at high concentration. They were most common around small blood vessels and appeared to be nerve endings, with granular intracellular components (fig. 14). The significance of this observation is not clear because anti- $\beta$-melanotropin continued to permit staining of the pars nervosa after absorption with $\beta$-melanotropin even though no color at all appeared in the pars intermedia.

\section{The effect of adrenalectomy}

Pars distalis. Previously we (Baker et al., '70) reported that seven days after adrenalectomy of rats some corticotropic cells are enlarged in both sexes. In this study at two weeks after adrenalectomy, most corticotropic cells as revealed immunochemically with anti- $\beta^{1-24_{-}}$or anti- $\beta_{\mathbf{p}^{17-39}}$ corticotropin were markedly hypertrophied and possessed enlarged nuclei (figs. 2, 8). The general cytoplasm was stained, as well as granules located peripherally (fig. 8) in many of the hypertrophied corticotropic cells. Although no mitotic figures were found, the number of corticotropic cells was clearly increased in most of the adrenalectomized rats (figs. 1, 2). After adrenalectomy there was a rather wide range in the staining intensity of the hypertrophied corticotropic cells. At three weeks the magnitude of the cytological response to adrenalectomy had regressed somewhat.

At two and three weeks after adrenalectomy the cells staining with anti- $\beta$ melanotropin and anti- $\alpha$-melanotropin remained unchanged.

Pars intermedia. Adrenalectomy elicited little change in the pars intermedia. At two and three weeks a slight cellular enlargement sometimes seemed evident in the pars intermedia proper but it could not be demonstrated consistently (figs. 9, $10)$. A significant modification in staining intensity did not occur with anti- $\beta^{1-24}$ corticotropin or anti- $\beta$-melanotropin while a slight decline was sometimes evident if anti- $\beta_{\mathrm{P}}{ }^{17-39}$-corticotropin was used.

Pars nervosa. Following adrenalectomy, the structures staining with anti- $\beta$-melanotropin in the pars nervosa were somewhat more densely arranged.

\section{The effect of cortisol administration}

Pars distalis. Except for a few cells, administration of high doses of cortisol acetate obliterated the stainability of most corticotropic cells when demonstrated with either anti- $\beta^{1-24}$-or anti- $\beta_{\mathrm{P}^{17-39}}$-corticotropin (fig. 3 ). If some staining capacity was retained by corticotropic cells one could ascertain that they were as small or smaller than those in vehicle-treated controls. Conclusive demonstration of a loss in cell volume was difficult because corticotropic cells are so small in normal rats. In those cells stained immunochemically with anti$\beta$-melanotropin or anti- $\alpha$-melanotropin no significant alterations could be attributed to cortisol treatment.

Pars intermedia. Parenchymal cells of the pars intermedia proper either remained unchanged in size after cortisol treatment (fig. 11) or in certain rats appeared somewhat enlarged with "foamier" cytoplasm and greater dispersion of chromatin in the nucleus. With anti- $\beta^{1-24}$ - and anti- $\beta \mathbf{r}^{17-39}$ corticotropin (figs. 3,11 ), as well as with anti- $\beta$-melanotropin, a slight decrease in overall staining capacity of the lobe occurred.

\section{DISCUSSION}

Correlation of alterations in morphology with hormone content in the pars intermedia and pars distalis after adrenalectomy or cortisol administration should facilitate clarification of the origins of corticotropin and melanotropin because following adrenalectomy of rats, the pituitary content of corticotropin is increased manyfold at 14 and 21 days (Fortier, '59a) while after chronic treatment with cortisol it is re- 
duced greatly (Fortier, '59b). On the other hand, total melanotropin content of the hypophysis is unaffected by either treatment and the concentration is increased by only cortisol treatment (Gosbee et al., '70).

The pars distalis as a source of corticotropin. Although Kraicer, Herlant and Duclos ('67) reported enlargement of chromophobes (a subclass of acidophils as revealed by the Herlant tetrachrome procedure ) after adrenalectomy, and reduction in their size after cortisol administration, later Kraicer and his colleagues (Gosbee et al., '70) maintained that cytological changes elicited in the hypophysis by these treatments are restricted to the pars intermedia. It is now clear from immunochemical staining (Baker et al., '70) and studies with immunofluorescence (Hess et al., '68) that one week after adrenalectomy numerous corticotropic cells in the pars distalis are mildly hypertrophied; further at two and three weeks after the operation, when the augmentation in pituitary corticotropic content reaches its highest level (Fortier, '59a), the response of corticotropic cells is also maximal with respect to hypertrophy and number of cells affected. This conclusion is supported by the electron microscopic observations of Nakayama et al. ('69), Siperstein and Miller ('70), and Pelletier and Racadot ('71). Two of these groups (Siperstein and Miller, '70; Pelletier and Racadot, '71) also showed that a single injection of glucocorticoid into the adrenalectomized rat increases the storage of secretory granules, in accord with enhancement of pituitary corticotropic content (Fortier, '59b). Continuation of cortisol treatment for one week or longer makes most corticotropic cells unidentifiable by ultrastructural (Siperstein and Miller, '70) or immunochemical characteristics. Thus, predictable cytological changes do occur in the pars distalis in concert with experimental alteration in the pituitary level of corticotropin.

Although the rare cells of the pars distalis that stain immunochemically with anti- $\beta$-melanotropin, or the more numerous ovoid cells revealed with $\alpha$-melanotropin, might produce melanotropin, experimental verification of this inference has not been possible because the functional role of these hormones in mammals is so poorly understood. The cells that accept anti- $\beta$ melanotropin are probably too scarce to affect the total melanotropin content of the gland and the minor cellular changes that may have occurred following these treatments were undoubtedly inconsequential. Thus, there is a close parallelism between cytological changes in corticotropic cells in the pars distalis and shifting levels of corticotropin in the gland, but following adrenalectomy or administration of cortisol both the content of $\beta$-melanotropin (Gosbee et al., '70) in the hypophysis and the possible cells of origin in the pars distalis remain unaffected.

The pars intermedia as a source of corticotropin. Several investigators agree that the pars intermedia is altered by adrenalectomy and on the basis of this and other observations have suggested that it also secretes corticotropin. Kobayashi ('65, 69) reported an enlargement of "light" cells, engorgement of their cytoplasm with both clear and dense vesicles, hypertrophy of the Golgi apparatus and rough endoplasmic reticulum and no change in the smaller "dark" cells. In contrast, Gosbee et al. (70) reported a marked increase in the relative number of shrunken, "dark" cells after adrenalectomy as observed with light microscopy and concluded that their "findings are consistent with recent reports [by Kobayashi] of electron microscopic changes in the pars intermedia associated with altered secretion of ACTH." In our preparations from control animals differentiation of parenchymal cells of the pars intermedia into light and dark varieties was not possible on the basis of criteria used by Gosbee et al. ('70) or electron microscopists, nor did "dark" cells accumulate after adrenalectomy. The increased number of small dark cells described by these investigators after adrenalectomy may have been dependent on the type of fixative used or unusual treatment of the tissue during excision. At any rate shrinkage of a cell with condensation of cytoplasm and nucleoplasm are not commonly considered indicative of accelerated synthesis and release of a cell product. Dark cells identified with electron microscopy were interpreted by Kobayashi to be degenerative in nature.

Gosbee et al. ('70) believe the changes in cell proliferation elicited in the partes 
intermedia and distalis by adrenalectomy and cortisol administration also indicate that the pars intermedia secretes corticotropin. Thus, they found an increase in the labeling index of the pars intermedia after administration of ${ }^{3} \mathrm{H}$-thymidine with no change in the pars distalis following adrenalectomy and a fall after cortisol administration only in the pars intermedia. On the contrary, Crane and Loomes ('67) observed an increased labeling index in both lobes at one and two weeks after adrenalectomy and a fall only in the pars distalis after treatment with cortisol.

As pointed out previously by others, immunochemical staining of the pars intermedia with antiserums to $a_{\mathrm{P}}$-corticotropin and $\beta^{1-24}$-corticotropin may not be convincing evidence for the presence of corticotr pin because the molecules of corticotropin and $\beta$-melanotropin in that lobe contain an identical seven-amino acid sequence (Evans et al, ,66) making probable cross-reaction between each hormone and the antiserum of the other. However, in our control studies such cross-reaction was not demonstrable. More crucial is the observation made by Phifer and Spicer ('70) and by us that the pars intermedia stains with anti- $\beta_{\mathrm{P}}{ }^{17-39}$-corticotropin because this sequence of amino acids does not occur in any known type of melanotropin molecule. Assuming that rat corticotropin includes a similar or identical sequence, this finding is a strong indication that the pars intermedia contains corticotropin.

Further, Rochefort et al. ('59) and Mialhe-Voloss ('58) have shown that the posterior hypophysis (probably including both pars nervosa and pars intermedia) contains significant corticotropic activity. Since the pars intermedia, but not the pars nervosa, stains immunochemically with antiserum to corticotropin this hormone is probably restricted to the pars intermedia.

The structural changes in the pars intermedia reported by others to follow adrenalectomy or glucocorticoid administration might be mediated by the expected disturbance in the metabolism of electrolytes and water since increasing evidence indicates that a functional relationship exists between the intermediate lobe and the levels of electrolytes and water in the body. Thus, $x$-melanotropin causes natriuresis in both hypophysectomized and adrenalectomized rats (Orias and McCann, '72). Also, the pars intermedia appears to respond to changes in the volume and osmolarity of the blood. For example, provision of $2 \% \mathrm{NaCl}$ solution to rats as drinking fluid may increase mitotic activity and the number of small dark cells in the pars intermedia (Duchen, '62). Further, when the hypothalmo-neurohypophyseal syst $\in$ m is stimulated in certain mammalian species by deprivation of salt or water the pars intermedia and its constituent cells become smaller; contrariwise, damage to this system leads to hyperplasia of the pars intermedia (Legait, '63).

In conclusion, immunoche mical staining provides strong evidence that corticotropin occurs in the pars intermedia of the rat. However, failure of the pars intermedia to respond to alteration in the level of circulating adrenocortical steroids with more than minor structural change suggests that production of corticotropin by the pars intermedia is controlled by a different mechanism than is its secretion by the pars distalis; as a corollary one may infer that the fluctuating demands of the body for adrenocortical hormone are met by secretion of corticotropin from the pars distalis. The pars distalis does not seem to be involved in the production of $\beta$-melanotropin.

\section{ACKNOWLEDGMENT}

We are grateful to Mrs. Ya-Yen Yu for her skillful assistance.

\section{LITERATURE CITED}

Baker, B. L. 1970 Studies on hormone localization with emphasis on the hypophysis. J. Histochem., 18: 1-8.

Baker, B. L., S. Pek, A. R. Midgley, Jr. and B. E. Gersten 1970 Identification of the corticotropin cell in rat hypophyses with peroxidaselabeled antibody. Anat. Rec., 166: 557-567.

Crane, W. A. J., and R. S. Loomes 1967 Effect of age, sex, and hormonal state on tritiated thymidine uptake by rat pituitary. Brit. J. Cancer, 21: 787-792.

Duchen, L. W. 1962 The effects of ingestion of hypertonic saline on the pituitary gland in the rat: A morphological study of the pars intermedia and posterior lobe. J. Endocr., 25: 161-168.

Evans, H. M., L. L. Sparks and J. S. Dixon 1966 The physiology and chemistry of adrenocorticotrophin. In: The Pituitary Gland. Anterior Pituitary. Vol. 1. G. W. Harris and B. T. Donovan, eds. Univ. Calif. Press, Berkeley, pp. 317373. 
Fortier, C. 1959a Pituitary ACTH and plasma free corticosteroids following bilateral adrenalectomy in the rat. Proc. Soc. Exp. Biol. Med., 100: $13-16$.

$1959 \mathrm{~b}$ Effect of hydrocortisone on pituitary ACTH and adrenal weight in the rat. Proc. Soc. Exp. Biol. Med., 100: 16-19.

Gosbee, J. L., J. Kraicer, A. J. Kastin and A. V. Schally 1970 Functional relationship between the pars intermedia and ACTH secretion in the rat. Endocrinology, 86: 560-567.

Hess, R., D. Barratt and J. Gelzer 1968 Immunofluorescent localization of $\beta$-corticotropin in the rat pituitary. Experientia, 24: 584-585.

Kobayashi, Y. 1965 Functional morphology of the pars intermedia of the rat hypophysis as revealed with the electron microscope. II. Correlation of the pars intermedia with the hypophyseo-adrenal axis. Z. Zellforsch., 68: 155-171.

1969 Functional morphology of the pars intermedia of the rat hypophysis as revealed with the electron microscope. IV. Effects of corticosterone on the pars intermedia of intact and adrenalectomized rats. Gunma Symp. Endocrinology, 6: 107-122.

Kraicer, J,, M. Herlant and P. Duclos 1967 Changes in adenohypophyseal cytology and nucleic acid content in the rat 32 days after bilateral adrenalectomy and the chronic injection of cortisol. Canad. J. Physiol. Pharm., 45: 947-956.

Kurosumi, K., T. Matsuzawa and S. Shibasaki 1961 Electron microscope studies on the fine structures of the pars nervosa and pars intermedia, and their morphological interrelation in the normal rat hypophysis. Gen. Comp. Endocr., 1: $433-452$.

Kurosumi, K., T. Matsuzawa and E. Fujie 1962 Histological and histochemical studies on the rat pituitary pars intermedia. Arch. Hist. Jap., 22: 209-227.

Legait, E. 1963 Cytophysiologie du lobe intermédiaire de l'hyfophyse des mammifères. In: Cytologie de L'Adénohypophyse. J. Benoit and C. Da Lage, eds. Editions du Centre National de la Recherche Scientifique, Paris, pp. 215-227.

$\mathrm{Li}, \mathrm{C} . \mathrm{H}, 1959$ Proposed system of terminology for preparations of adrenocorticotropic hormone. Science, 129: 969-970.

Mialhe-Voloss, C. 1958 Posthypophyse et activite corticotrope. Acta Endocr., Suppl. 35.
Midgley, A. R., Jr., G. D. Niswender, V. L. Gay and L. E. Reichert, Jr. 1971 Use of antibodies for characterization of gonadotropins and steroids. Rec. Progr. Horm. Res., 27: 235-301.

Nakane, P. K. 1970 Classifications of anterior pituitary cell types with immunoenzyme histochemistry. J. Histochem. Cytochem., 18: 9-20.

Nakane, P. K., and G. B. Pierce, Jr. 1967 Enzyme-labeled antibodies for the light and electron microscopic localization of tissue antigens. J. Cell Biol., 33: 307-318.

Nakayama, I., P. A. Nickerson and F. R. Skelton 1969 An ultrastructural study of the adrenocorticotrophic hormone-secreting cell in the rat adenohypophysis during adrenal cortical regeneration. Lab. Invest., 21: 169-178.

Orias, R., and S. M. McCann 1972 Natriuretic effect of alpha melanocyte stimulating hormone (a-MSH) in hypophysectomized or adrenalectomized rats. Proc. Soc. Exp. Biol. Med., 139: 872-876.

Pelletier, G., and J. Racadot 1971 Identification des cellules hypophysaires sécrétant l'ACTH chez le rat. Z. Zellforsch., 116: 228-239.

Phifer, R. F., and S. S. Spicer 1970 Immunohistologic and immunopathologic demonstration of adrenocorticotropic hormone in the pars intermedia of the adenohypophysis. Lab. Invest., 23: 543-550.

Porte, A., M. J. Klein, M. E. Stoeckel and F. Stutinsky 1971 Sur l'existence de cellules de type "corticotrope" dans la pars intermedia de l'hypophyse du rat. Etude au microscope électronique. Z. Zellforsch., 115: 60-68.

Purves, H. D., and E. G. Bassett 1963 The staining reactions of pars intermedia cells and their differentiation from pars anterior cells. In: Cytologie de L'Adénohypophyse. J. Benoit and C. Da Lage, eds. Editions du Centre National de la Recherche Scientifique, Paris, pp. 231-238.

Riniker, B., P. Sieber, W. Rittel and H. Zuber 1972 Revised amino-acid sequences for porcine and human adrenocorticotrophic hormone. Nature New Biol., 235: 114-115.

Rochefort, G. J., J. Rosenberger and M. Saffran 1959 Depletion of pituitary corticotrophin by various stresses and by neurohypophysial preparations. J. Physiol., 146: 105-116.

Siperstein, E. R., and K. J. Miller 1970 Further cytophysiologic evidence for the identity of the cells that produce adrenocorticotrophic hormone. Endocrinology, 86: 451-486. 


\section{Abbreviations}

$\mathrm{N}$, pars nervosa

I, pars intermedia

$\mathrm{D}$, pars distalis

\section{PLATE 1}

EXPLANATION OF FIGURES

Figures 1-6 represent one-half of the hypophysis sectioned on a horizontal plane. $\times 38$.

I Female control rat; staining with anti- $\beta_{\mathrm{P}^{17-39}}$ corticotropin. The pars intermedia is well-stained and small corticotropic cells appear throughout the pars distalis.

2 Female rat 14 days after adrenalectomy; staining with anti- $\beta_{\mathbf{p}^{17-39}}$. corticotropin. Corticotropic cells of the pars distalis are enlarged and probably increased in relative number.

3 Female rat following treatment with cortisol; staining with anti- $\beta_{\mathbf{P}^{17-39}}$ corticotropin. As compared with the control (fig. 1), staining intensity of the pars intermedia is reduced and only a few corticotropic cells are visible in the pars distalis (arrow).

4 Female control rat; staining with anti- $\beta_{\mathrm{p}^{1-24}}$-corticotropin. The overall reaction of the pars intermedia and pars distalis is similar to that obtained with anti- $\beta_{\mathrm{P}}{ }^{17-39}$-corticotropin (fig. 1 ). 

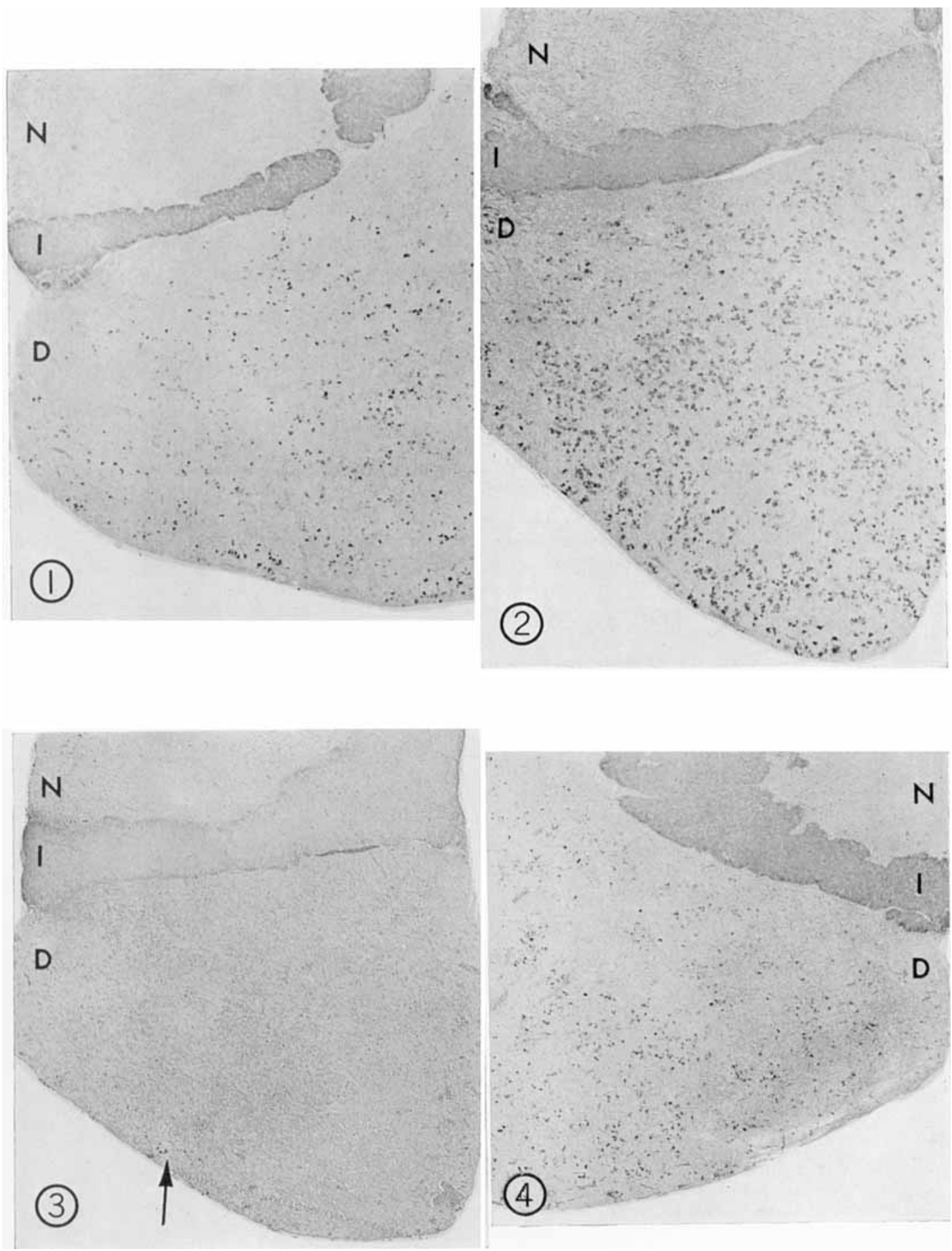
PLATE 2

EXPLANATION OF FIGURES

5 Female control rat; staining with anti- $\beta$-MSH. Staining is of moderate intensity in the pars nervosa and intense in the pars intermedia. $\times 38$.

6 Female control rat; staining with anti-a-MSH. The partes nervosa and intermedia are unstained while some cells appear in the pars distalis that are most numerous along the cephalic and caudal borders of the lobe. $\times 38$.

7 Female control rat; corticotropic cells (c) stained with anti- $\beta_{\mathbf{p}^{17-39}}$ corticotropin. $\times 1000$.

8 Female rat 14 days after adrenalectomy; corticotropic cells staining with anti- $\beta_{1}{ }^{17-39}$-corticotropin. As compared with those in figure 7 , corticotropic cells (c) are enlarged and vary in their staining capacity. In one instance, granules are visible peripherally (arrows) in the cell around an enlarged Golgi region. $\times 1000$. 
ORIGIN OF CORTICOTROPIN AND MELANOTROPIN

PLATE 2

Burton L. Baker and Sister Thérése Drummond

PLATE 3

EXPLANATION OF FIGURES

Figures 9-13 illustrate a region of the hypophysis extending from the pars distalis (D) above through the residual cleft (C), marginal zone of the pars intermedia (M), pars intermedia proper (I), and into the pars nervosa $(\mathrm{N}), \times 400$.

9 Control female rat; staining with anti- $\beta_{\mathrm{P}}{ }^{17-39}$-corticotropin. The marginal zone of the pars intermedia is unstained. Most cells of the pars intermedia proper are stained but some (arrows) are not colored.

10 Female rat 14 days after adrenalectomy; staining with anti- $\beta_{\mathrm{P}}{ }^{17-39}$ corticotropin. Staining intensity of the pars intermedia proper is reduced slightly as compared with the control (fig. 9). There is no cellular enlargement in this specimen.

11 Female rat following treatment with cortisol; staining with anti- $\beta_{\mathrm{P}}{ }^{17-39}$. corticotropin. Staining intensity is reduced somewhat as compared with the control (fig. 9 ).

12 Female control rat; staining with anti- $\beta^{1-24}$-corticotropin. In contrast to the lack of color in the marginal zone, the cells of the pars intermedia are rather uniformly stained. The darkest cells border the pars nervosa. 

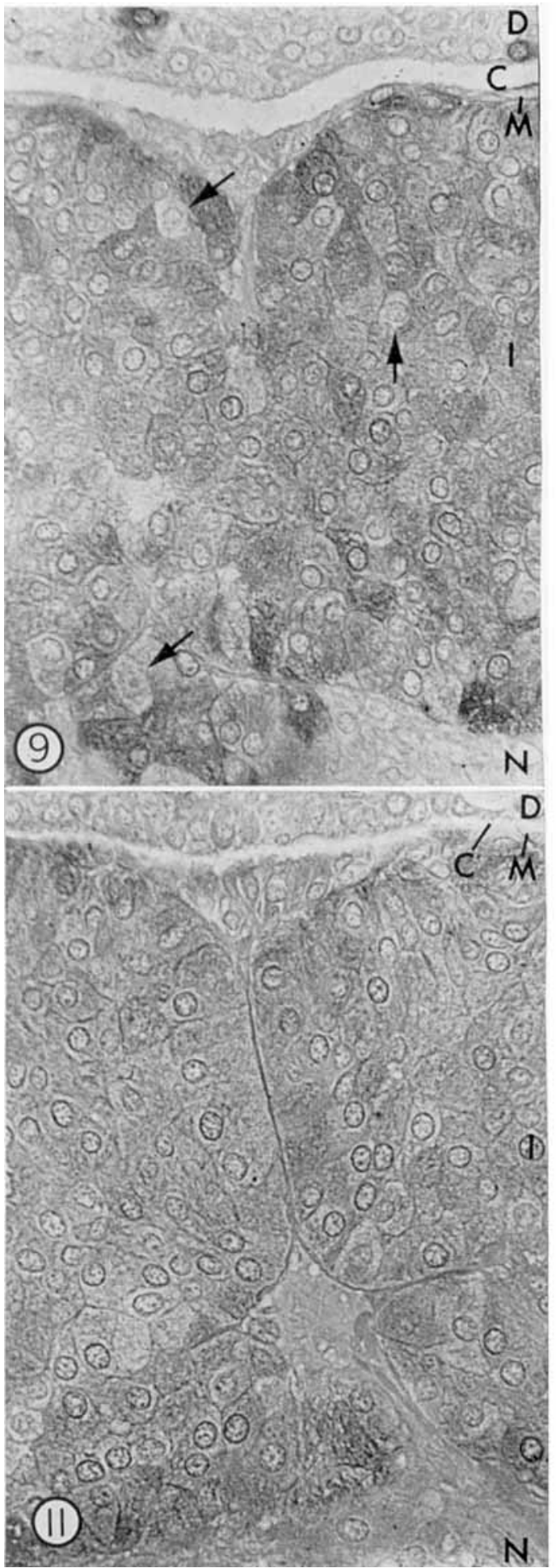
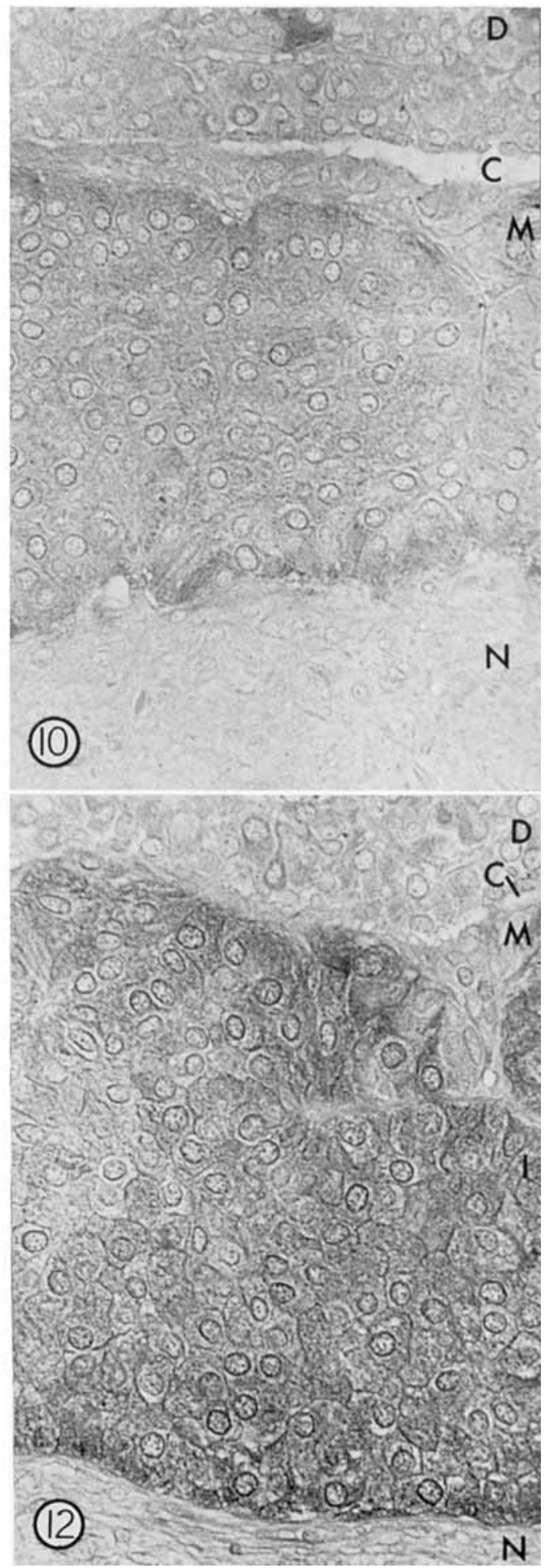
PLATE 4

EXPLANATION OF FIGURES

13 Female control rat; staining with anti- $\beta$-melanotropin. The marginal zone is uncolored while cells of the pars intermedia proper are stained with rather uniform intensity except for the apices of the cells bordering the marginal zone and pars nervosa, which are much darker. small areas of the pars nervosa are stained.

14 Pars nervosa of a female control rat; staining with anti- $\beta$-melanotropin. Numerous structures that appear to be nerve endings contain dark granules. These are most numerous around capillaries (cap.). $\times 400$.

15 Pars intermedia of a female control rat; staining with anti- $\beta_{1},{ }^{1-3 y_{-}}$ corticotropin. Some cells (X) show little or no cytoplasmic staining. In others granules (arrows) are evident, these being most numerous alongside the pars nervosa. $\times 1000$.

16 Pars intermedia of a female control rat; staining with anti- - $^{1-21}$ corticotropin. The general stainability of cells in the pars intermedia proper is illustrated. Granulation (arrows) appears in the cytoplasm; the darkest cells border the pars nervosa and a connective tissue septum. $\times 1000$. 


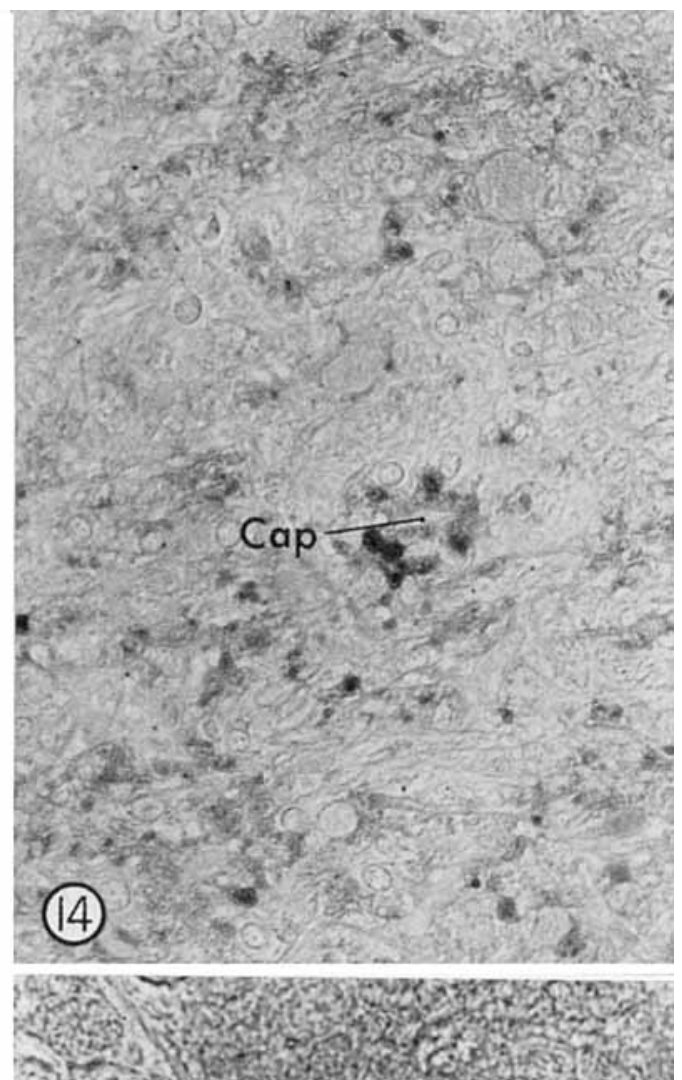

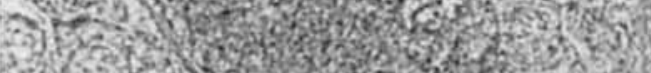

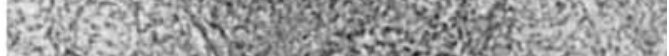

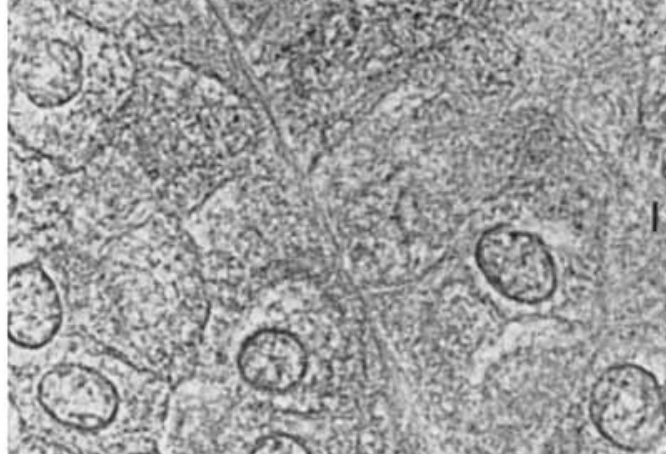

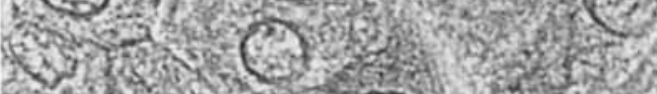

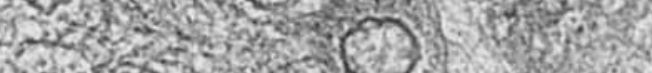



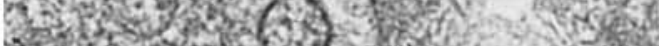

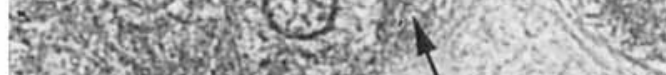

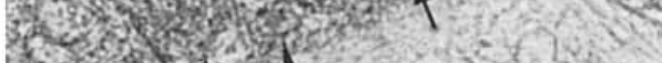
(16) $\mathrm{N}+\mathrm{T}, \mathrm{N}$ 